\title{
Infrastructure projects in Tanzania: Obstacles and Challenges to improve infrastructure
}

\author{
By Irene Joshua NDOSSY*
}

\begin{abstract}
Infrastructure projects spend a lot of funds for development and management. Tanzania like other countries has been attracting many donors to establish, expand and manage a variety of infrastructure projects ranging from road and airport construction, water and electricity supplies as well as ports like the Port of Dar es Salaam, Tanga and Mtwara. However, the country is faced with some challenges to include lack of transparency in the infrastructure projects, corruption, high dependence on donor funds and poor management of the projects as well as lack of human capital to supervise the projects. This desk review study explores the infrastructure projects in Tanzania by looking on their challenges.
\end{abstract}

\section{A. Background}

The word infrastructure means the basic structure of an organization or system which is necessary for its operation, esp. public water, energy, and systems for communication and transport (Cambridge dictionary, 2020). Also, infrastructure connotes the basic systems and services that are needed in order to support an economy, for example, transport and communication systems and electricity and water supplies (Cambridge dictionary, 2020). For the purpose of this study, infrastructure will mean services which improve the economy of the country such as electricity and water supply, transport and communication to include roads, airports or ports, which spend a lot of public funds.

Infrastructure in its various forms plays a critical role in growth and development in Africa and elsewhere. Some types of infrastructure are important because they contribute to growth processes. For example, four different sets of economic infrastructure include (a) transport infrastructure (road, rail, ports and airports), (b) power generation (c) the information and communications (ICT) highway (d) and irrigation for the agricultural sector. By contrast, social infrastructure such as water and sanitation predominantly delivers developmental outcomes (NEPAD \& UN, 2015) ${ }^{1}$. These two sets of economic and social infrastruc-

* Irene Joshua Ndossy is a civil servant working at the Arusha district as a Division Officer, and she is also a Legal Counsel serving at the High Court of Tanzania. She also holds a Master degree in Governance and Leadership, and is a member of the Appointment and Employment Relations Committee of the Red Cross Society of Tanzania. Contact: mail: Irene.ndossy@gmail.com, Mobile phone: 0755063226.

1 NEPAD \& UN (2015). Infrastructure development within the context of Africa's cooperation with new and emerging development partners. Addis Ababa : African Union. 
ture interact. For example, a transport system which is distributed throughout the economy, including to rural areas and to regions of relatively low income, has important development impacts. Similarly, good sanitation and sewerage improves the welfare of workers and is required for many products in export markets and thus contributes to growth (NEPAD \& $\mathrm{UN}, 2015)^{2}$. Further important characteristic of infrastructure is the distinction between hard and soft infrastructure. According to NEPAD \& UN, the former infrastructure is reflected in physical investments (for example, roads, power plants, ICT networks, irrigation networks, water treatment plants), whilst the latter refers to the institutions in which the hard infrastructure is embedded (for example, customs clearance procedures and sanitation system design).

A study of 100 countries over the period between 1960 and 2000 confirmed both the growth enhancing and income distributing consequences of increased infrastructural investment (Calderon and Serven, 2004) 3 $^{3}$ The positive distributional impact of investment in infrastructure is confirmed in an analysis of progress towards meeting the MDG targets, showing a positive relationship between infrastructure investment and reductions in infant mortality and improvements in nutrition (Fay et. al, 2005) ${ }^{4}$. Despite the clear link between growth, development and infrastructure and the consequently high payoffs to investment in infrastructure, a variety of studies have identified a significant infrastructural deficit in Africa. This deficit applies to both economic and social infrastructure and has major implications for economic growth. Studies estimate that infrastructure deficits depressed enterprise productivity by around $40 \%$ in SSA (Escribano et al, 2008) ${ }^{5}$, and that this negative impact was greater the lower the per capita income of the economy. A World Bank review of the state of infrastructure in Africa concluded that for most countries, the negative economic impact of deficient infrastructure is at least as large as that associated with crime, red tape, corruption, and financial market constraints (Foster et al, 2008) .

Beyond the low level of infrastructure provision in aggregate is its poor distribution, particularly with respect to social infrastructure. For example, the proportion of Africa's population having access to piped water, electricity, flush toilets and landline telephony is considerably higher in urban areas than in rural areas. Further, progress in the provision of social infrastructure has at best been slow, and more typically nonexistent. This contrasts

2 NEPAD \& UN (2015). Infrastructure development within the context of Africa's cooperation with new and emerging development partners. Addis Ababa : African Union.

3 Calderón, César; Servén, Luis. 2004. The Effects of Infrastructure Development on Growth and Income Distribution. Policy Research Working Paper; No.3400. World Bank, Washington, D.C.C World Bank.

4 Fay N, et al. (2005) Structure of the prion Ure2p in protein fibrils assembled in vitro. J Biol Chem 280(44):37149-58.

5 Escribano, A., Fosfuri, A. and Tribó, J.A. (2008), "Managing external knowledge flows: the moderating role of absorptive capacity", Research Policy, Vol. 38 No. 1, pp. 96-105.

6 Foster et al, 2008 V., W. Butterfield, C. Chen and N. Pushak (2008), Building Bridges: China's Growing Role as Infrastructure Financier for Africa, Trends and Policy Options: Infrastructure No. 5, Washington: The World Bank. 
with other low income economies in which there has often been substantial progress in infrastructure provision. For example, SSA had three times more generating capacity per capita in 1970 than India, but by 2000 India had overtaken Africa and had twice as much per capita capacity as SSA (Foster et al, 2008). Thus beyond the poor availability of infrastructure is the slow rate of progress. It is also cited $t$ when infrastructural activities are part of larger initiatives (such as investments in the commodities sector), it is difficult to unravel the specific infrastructural element in these projects. Likewise, there is often considerable unclarity about the size of many projects; for example, China's Sicomines project in the DRC has variously been cited as involving investments of between \$6bn and \$12bn, where repayment is made in commodities or through commodity receipts (as in the Angola Mode) the costs are uncertain even to the contracting parties. And, finally, beyond the uncertainty of data on the value and distribution of activities, there is a gap between commitments and disbursements. ${ }^{7}$

A further challenge confronting Africa's infrastructural development is that, by necessity, much of the economic infrastructure requires cross-border cooperation. This is particularly evident in the case of transport and power which suffer from classic externality challenges. Although there are some cases where an individual user may be so large that it alone can pay for the costs of the infrastructure (for example, a large power plant, or a point-to-point railway or pipeline between the commodity extraction site and the point of commodity export) it is generally the case that no single user may be able to make enough use of the infrastructure to cover its costs. For example, the proposed Central Corridor in East Africa which potentially links Tanzania, Rwanda, Uganda, Burundi, the Eastern DRC and parts of Kenya with the coast requires the cooperation, resources and support of all of the relevant governments, as well as support from multilateral organisations such as the African Development Bank and the World Bank (NEPAD \& UN, 2015). Despite Tanzania being of the counties receiving donor funds for infrastructure, it is unknown what obstacles and challenges the country is facing in the development and management of infrastructure projects. Therefore, this study adopts the desk review of literature to answer the question: What obstacles and challenges are facing infrastructure projects in Tanzania?

\section{B. Literature review}

\section{Global Infrastructure projects and their challenges}

A study Garemo et al (2016) asserts that In order to sustain global growth forecasts, \$1 trillion more needs to be spent on infrastructure globally, most of it in emerging markets and

7 Foster et al, 2008 V., W. Butterfield, C. Chen and N. Pushak (2008), Building Bridges: China's Growing Role as Infrastructure Financier for Africa, Trends and Policy Options: Infrastructure No. 5, Washington: The World Bank. 
developing countries ${ }^{8}$. In Africa, the current yearly $\$ 80$ billion investment commitment in 2015 needs to double by 2030. The sectors with the largest infrastructure challenges are energy and transport. Power demand and access are quickly growing, while road and rail density is the lowest in Africa in the entire developing world (World Bank, 2017) ${ }^{9}$. At least $80 \%$ of goods and $90 \%$ of passengers are still transported on roads, mostly of poor quality. More railway is urgently needed to transport more efficiently primary commodities, the main exports of the continent (ICA, 2014) ${ }^{10}$.

While these projects are usually funded through a mix of public budget, DFI and private funding, such infrastructure shortage can only be met by increasing the share of private capital. Investors are increasingly interested in such projects due to their long-term, predictable and relatively high returns. They also deem co-financing by DFIs a form of validation, because they provide guarantees, carry out socio-economic evaluation of investments and set environmental and integrity standards (Gutman et al., 2015). In regard, DFIs bring valuable local insight that foreign quarter of private capital in infrastructure projects takes the form of concessional debts from China (ICA, 2016) ${ }^{11}$. This is hardly sustainable, as African governments might default on the amassed debts. Instead, there is a need to shift from debt-fuelled infrastructure development towards public-private partnerships (PPP) and blended finance models (Jayaram et al., 2017'12; Arezki, Sy, 2016) ${ }^{13}$. DFIs are actively encouraging these solutions and governments, such as the Kenya, Nigeria, Uganda and South Africa are slowly establishing PPPs mostly in energy (78\%) and transport (22\%) projects (World Bank, 2017) ${ }^{14}$.

It is pointed by Klomegah (2019) African Union officials have repeatedly urged African leaders to prioritise Africa's Agenda 2063, a strategic framework for delivering on Africa's goal for inclusive and sustainable development, and the United Nations' Sustainable Development Goals (SDGs). In realising this need, Russia has recently repositioned itself to become a major partner with Southern Africa. Russia's interest is in line with SADC priorities as highlighted by the following priorities of foreign economic strategy in the region (i)prospecting, mining, oil, construction, mining, purchase of gas, oil, uranium, and bauxite assets (Angola, Namibia and South Africa), (ii) construction of power facilities: hy-

8 Nicklas Garemo, Martin Hjerpe, Jan Mischke, Robert Palter, Jonathan Woetzel (2016). Bridging global infrastructure gaps, McKinsey Global Institute.

9 World Bank (2017). Africa's pulse, World Bank Group, Washington, DC: World Bank.

10 Infrastructure Consortium for Africa - ICA (2014). Things You Should Know About Infrastructure in Africa, Abidjan.

11 Infrastructure Consortium for Africa - ICA (2016). Infrastructure Financing Trends in Africa 2015, Abidjan.

12 Kartik Jayaram, Omid Kassiri, Irene Yuan Sun (2017). The closest look yet at Chinese economic engagement in Africa, McKinsey\&Company Report.

13 Rabah Arezki, Amadou Sy (2106). Financing Africa's infrastructure deficit: From development banking to long-term investing, The Brookings Institute, Global Views, No. 2.

14 World Bank (2017). Africa's pulse, World Bank Group, Washington, D.C: World Bank. 
droelectric power plants on the River Congo (Angola, Namibia, and Zambia,) and nuclear power plants (South Africa), (iii)creation of a floating nuclear power plant, and South African participation in the international project to build a nuclear enrichment centre in Russia; (iv) railway construction (Angola) ${ }^{15}$. However, policy implications of individual counties have to a great extent contributed to slow progress in infrastructure, for example, corruption risks discourage the mutually beneficial match of high return projects for private investors and closing Africa's infrastructure gap (Sobják, 2018) ${ }^{16}$.

\section{Tanzanian infrastructure and their challenges}

World Bank (2026) remarks that Tanzania needs to increase investments in infrastructure and human capital to further unlock its growth potential while enabling the private sector to create more jobs ${ }^{17}$. According to the update, titled; "The Road Less Traveled: Unleashing Public Private Partnerships in Tanzania with increasing fiscal challenges due to declining aid, low domestic revenue mobilization, high expenditure pressure for clearance of payment arrears and debt service, Tanzania will need to find alternative sources for financing its huge development needs (World Bank, 2016) ${ }^{18}$. Further, Tanzania has had a mixed experience with public private partnerships, what is needed now is to embrace these important past lessons and combine them with best practices from the largest emerging economies such as Brazil, Chile, Mexico and India and develop a strong PPP programme that addresses the country's infrastructure development challenges and generates jobs. For example, the government of Tanzania launched the TSh340bn (\$150m) Resilient Natural Resource Management for Tourism and Growth (REGROW) project with the World Bank's International Development Association to improve conservation management and infrastructure in southern Tanzania. Slated for completion in September 2023, a key focus of the initiative will be to improve connectivity to the southern safari circuit, a 77,000-sq-km area of game reserves and national parks. Despite its high tourism potential, the region currently attracts only $1 \%$ of all tourists to Tanzania due to a lack of transport links such as roads and airstrips, with visitors preferring to visit the country's well-established northern circuit (Oxford Business Group, 2018) ${ }^{19}$.

15 Klomegah, Kester Kenn (2019). Infrastructure Development Key to Africa's Growth. IDN Newsletter, April 24, 2019.

16 Sobják, Anita, (2018). Corruption Risks in Infrastructure Investments in Sub-Saharan Africa. MPP, Blavatnik School of Government, University of Oxford, United Kingdom.

17 World Bank (2016). Tanzania Needs to Invest More on Infrastructure and Human Capital to Improve its Competitiveness and Create More Productive Jobs. Dar es Salaam: World Bank.

18 World Bank, (2016).Tanzania Economic Update: More, Better Infrastructure, Increased Human Investment and Renewed Public-Private Partnerships Key to Poverty Reduction in Tanzania.Dar es Salaam: World Bank.

19 Oxford Business Group (2018). On improving public-private cooperation from The Report: Tanzania 2018. 
Tanzania like other countries have overly optimistic ranking partly because their governments pursue effective investment promotion campaigns abroad (e.g. Rwanda and Ghana). More common for Sub-Saharan Africa is, however, that corruption perceptions overrate risks for investors because the continent is often viewed as a homogeneous block. Essentially, African countries with relatively better established governance systems have less de facto corruption risk, than emerging markets popular among investors, like Brazil or China (David, $20120^{20}$.According to him, investors' perceptions remain guided by national corruption index rankings like TI's CPI, which ranks Tanzania (116) and Ivory Coast (108) much lower, than China (79) and Brazil (79). On one hand, genuine governance and anticorruption reforms often remain unrecognised by risk perceptions (Collier, 2008, 88-91). Indeed, they are much fragile and can be easily reversed in the event of political changes, or if they were purely donor-driven (William, 2007) ${ }^{21}$. Likewise, a project is pursued on a political basis, rather than for its socio-economic rationale. For instance, a politician or political party promotes it to gain constituency, or as a subject of inter-institutional infighting. In an extreme case, a new administration might even withdraw support for a project initiated by the previous one, or it might expropriate assets - the most common fear of foreign investors (Sobjak, 2018) 22 . It is remarked by Sobjak (2018), in these cases, the project is exposed to increased risks of delays, suspension, lack of operational capacity, etc. Moreover, such projects are particularly conducive to wrongdoing throughout the project cycle, because in order to mask such defects, there is a high chance that further bribes will be paid (e.g. to obtain positive progress reports or audits).

\section{Methodology}

The analysis relies on combining evidence from existing literature (academic papers, policy reports by DFIs, World Bank and many institutions interesting in infrastructure projects worldwide such as ICA, and OECD).

\section{Opportunities Infrastructure projects in Tanzania}

According to available data o infrastructure projects in Tanzania,growth rates and growth drivers varied across the continent, with the less resource-dependent East African subregion continuing to record higher annual rates of growth of more than 5 per cent, largely because of performance in countries such as Djibouti, Ethiopia, Uganda and the United Republic of

20 David Lawler (2012). Frequently Asked Questions in Anti-Bribery and Corruption, John Wiley \& Sons Ltd.

21 William D. O. Paterson, Pinki Chaudhuri (2007). "Making Inroads on Corruption in the Transport Sector." In The Many Faces of Corruption: Tracking Vulnerabilities at the Sector Level, edited by J. E.

22 Sobják, Anita, (2018). Corruption Risks in Infrastructure Investments in Sub-Saharan Africa. MPP, Blavatnik School of Government, University of Oxford, United Kingdom. 
Tanzania (UNCTAD, 2018). Factors driving growth included, besides increased commodity prices, increased infrastructure investments. For instance, tourism and travel directly accounted for $4.7 \%$ of GDP in 2016, or TSh4.59trn (\$2.1bn), according to (WTTC, 2018). However, much of the expenditure driving growth was funded with borrowing from abroad in many cases, resulting in a return of the "high indebtedness" problem. By the late 2000s, debt relief programmes had substantially reduced the debt burden of African countries. But since then, countries have accumulated new debt and a number of African countries are currently being identified as being debt-distressed. With international interest rates set to rise, the health of these economies could deteriorate quickly, Tanzania in particular (UNCTAD 2018). Since independence there have been a number of government-led initiatives geared towards fostering the local construction industry. Such initiatives include the establishment of regulatory institutions, the liberalisation of the economy to attract local and foreign private investors to finance infrastructure development programs and the mobilisation of donor support in financing infrastructure projects to support the local economy (Clyde \& Co Tanzania, 2013) $)^{23}$.

\section{Challenges facing infrastructure projects in Tanzania}

For example, in addressing the constraints of the construction industry in Tanzania, the Construction Industry Policy, 2003 provides that, among other things, the Government of Tanzania (GoT) will (i) provide mechanisms to improve capacity and performance of the local contractors and consultants, (ii) improve public sector delivery capacity, (iii) improve the performance of the informal construction sector, (iv) promote export of goods and services. (v) improve quality and productivity, (vi) promote technological development ${ }^{24}$. However, the construction industry is still faced with several constraints such as long process for registering engineers and effective strategies to implement the policy framework; this requires the new construction policy to address the constraints and, among other things, develop a more effective institutional framework for sustainable infrastructure development and maintenance in the construction and civil engineering sectors for buildings and transportation.

A study by Ndulane (2015) on the assessment of challenges contributing to poor performance of small and medium contractors in Tanzania: a case study of Lindi region, found that poor financial and technical capabilities; fraudulent practices, lack of coordination between designers and contractors and; poor monitoring and feedback are ranked as the first three factors that affected Small Civil Contractors. In addition, lack of training on quality for staff, lack of management leadership and lack of previous experience of contractor were

23 Clyde \& Co Tanzania (2013). Structure of the construction industry in Tanzania. Dar es Salaam: Clyde \& Co Tanzania.

24 National Construction Industry Policy of 2003. 
also identified as factors related to contractors as the most critically ranked factors ${ }^{25}$. For instance, the central corridor links the port of Dar es Salaam by road, rail and inland waterways to Burundi, Rwanda, Uganda and Eastern part of the DRC and central and northernwestern Tanzania. Governed by the Central Corridor

Transit Transport Facilitation Agency (TTFA), a multilateral Agency established Sep 2006, formed by an Agreement by of Burundi, DRC, Rwanda, Tanzania and Uganda. Despite the importance of this corridor, the corridor is faced with poor involvement of Private Sector in corridor management, sustainable funding mechanism from stakeholders, value chain approach -the silo mentality, capacity alignment- infrastructure and human capital as well as resources integration (Mdawe, 2016) ${ }^{26}$. Choumert-Nkolo (2018) establishes that Tanzania's natural gas reserves are estimated at 57 trillion cubic feet and the emergence of gas revenues are expected to be a strong economic growth factor for the country. According to him, nearby communities are aware of the gas discoveries but know little about the topic, and they support gas developments but raise concern about the absence of tangible benefits. However, to be sustainable, this economic growth should be inclusive and should result from balanced investments between technical, human, environmental, and social capital ${ }^{27}$. In this case, lack of transparent for infrastructure project like this, may contribute to subrogate if the surrounding communities are unaware of tangible benefits.

\section{Conclusion and Recommendations}

According to desk review of empirical studies on infrastructure projects in Tanzania, there have been some opportunities to get DFIs in medium and large infrastructure projects such as expansion of ports road construction, and water and electricity supplies. However, lack of policy frameworks, lack of human capital, poor project management, high dependence on donor funds, and lack of governance (corruption) are among the contributing factors to slow implementation of infrastructure projects in Tanzania. In this case, it is recommended that Tanzania has to improve the credibility of the government entities in charge of infrastructure projects by implementing organisational controls to prevent bribery, such as the ISO 37001 Anti-bribery Management System Standard (DFID, 2015) ${ }^{28}$. Also, it should establish non-partisan government agencies that can participate in the public-private contract-

25 Ndulane, Francis (2015). An assessment of challenges contributing to poor performance of small and medium contractors in Tanzania: a case study of Lindi region. A Dissertation Submitted in Partial Fulfillment of the Requirements for Award of the Degree of Master of Science Accounting and Finance (Msc A\&F), Mzumbe University.

26 Mdawe, N. (2016). Challenges in Infrastructures of Transit Transport Corridors within East Africa Region. A paper presented at African Ports \& Maritime Conference held November 2016, Port Sudan.

27 Choumert-Nkolo, J (2018). Developing a socially inclusive and sustainable natural gas sector in Tanzania. Energy Policy, Vol.118, p.356 - 371.

28 Department for International Development - DFID (2015). Why corruption matters: understanding causes, effects and how to address them. Evidence paper on corruption. 
ing models instead of the direct involvement of the government. A good example is the Gabon Strategic Investments Fund known for its high professional standards and track record of delivering public-private infrastructure projects. Even if country-level corruption indicators take much to enhance, a trustworthy institution can win investors' confidence. Similarly, it should engage regularly with potential investors at the level of the relevant public entities (Ministry of Finance, Transport, Energy, etc.) to assure them about the governments' full commitment to the project (detect projects initiated for rent-seeking) and to manage and synchronise expectations from the project on all sides in order to avoid a misalignment of commercial and political interests (OECD, 2014) ${ }^{29}$.

\section{References}

Calderón, César; Servén, Luis. 2004. The Effects of Infrastructure Development on Growth and Income Distribution. Policy Research Working Paper; No.3400. World Bank, Washington, D.C: World Bank.

Choumert-Nkolo, J (2018). Developing a socially inclusive and sustainable natural gas sector in Tanzania. Energy Policy, Vol.118, p.356 - 371

Clyde \& Co Tanzania (2013). Structure of the construction industry in Tanzania. Dar es Salaam: Clyde \& Co Tanzania

David Lawler (2012). Frequently Asked Questions in Anti-Bribery and Corruption, John Wiley \& Sons Ltd

Department for International Development - DFID (2015). Why corruption matters: understanding causes, effects and how to address them. Evidence paper on corruption

Escribano, A., Fosfuri, A. and Tribó, J.A. (2008), "Managing external knowledge flows: the moderating role of absorptive capacity", Research Policy, Vol. 38(1), p. 96-105.

Fay N, et al. (2005) Structure of the prion Ure2p in protein fibrils assembled in vitro. $J$ Biol Chem 280(44):37149-58

Foster et al, 2008 V., W. Butterfield, C. Chen and N. Pushak (2008), Building Bridges: China's Growing Role as Infrastructure Financier for Africa, Trends and Policy Options: Infrastructure No. 5, Washington: The World Bank.

Infrastructure Consortium for Africa - ICA (2014). Things You Should Know About Infrastructure in Africa, Abidjan,

Infrastructure Consortium for Africa - ICA (2016). Infrastructure Financing Trends in Africa - 2015, Abidjan,

Kartik Jayaram, Omid Kassiri, Irene Yuan Sun (2017). The closest look yet at Chinese economic engagement in Africa, McKinsey\&Company Report

Klomegah, Kester Kenn (2019). Infrastructure Development Key to Africa's Growth. IDN Newsletter, April 24, 2019.

29 Organisation for Economic Co-operation and Development - OECD (2014). Foreign Bribery Report: An analysis of the crime of bribery of foreign public officials, 
Mdawe, N. (2016). Challenges in Infrastructures of Transit Transport Corridors within East Africa Region. A paper presented at African Ports \& Maritime Conference held November 2016, Port Sudan.

National Construction Industry Policy of 2003.

Ndulane, Francis (2015). An assessment of challenges contributing to poor performance of small and medium contractors in Tanzania: a case study of Lindi region. A Dissertation Submitted in Partial Fulfillment of the Requirements for Award of the Degree of Master of Science Accounting and Finance (Msc A\&F), Mzumbe University.

Nicklas Garemo, Martin Hjerpe, Jan Mischke, Robert Palter, Jonathan Woetzel (2016). Bridging global infrastructure gaps, McKinsey Global Institute

Organisation for Economic Co-operation and Development - OECD (2014). Foreign Bribery Report: An analysis of the crime of bribery of foreign public officials,

Oxford Business Group (2018). On improving public-private cooperation from The Report: Tanzania 2018

Rabah Arezki, Amadou Sy (2106). Financing Africa's infrastructure deficit: From development banking to long-term investing, The Brookings Institute, Global Views, No. 2,

Sobják, Anita, (2018). Corruption Risks in Infrastructure Investments in Sub-Saharan Africa. MPP, Blavatnik School of Government, University of Oxford, United Kingdom

William D. O. Paterson, Pinki Chaudhuri (2007). "Making Inroads on Corruption in the Transport Sector." In The Many Faces of Corruption: Tracking Vulnerabilities at the Sector Level, edited by J. E.

World Bank, (2016).Tanzania Economic Update: More, Better Infrastructure, Increased Human Investment and Renewed Public-Private Partnerships Key to Poverty Reduction in Tanzania.Dar es Salaam: World Bank. World Bank (2017). Africa's pulse, World Bank Group, Washington, DC: World Bank. 